\title{
Quantitative Significance of Dissolved Organic Losses Following Fragmentation of Kelp (Ecklonia maxima and Laminaria pallida)
}

\author{
R. C. Newell*, M. I. Lucas, B. Velimirov** and L. J. Seiderer \\ Zoology Department, University of Cape Town, Rondebosch 7700, South Africa
}

\begin{abstract}
Kelp Ecklonia maxima and Laminaria pallida both undergo fragmentation from the tip and thus release structural components as particulate matter and a dissolved fraction from the cell contents into the water column. Analysis of the dissolved fraction released as mucilage from kelp during fragmentation yielded a 92-94\% gravimetric recovery comprising 4.74-5.27 \% protein, $0.17-0.18 \%$ fat, $7.17-7.56 \%$ sugar and polyols, $4.77-5.01 \%$ alginate and $4.6-7.2 \%$ laminarin with $69.8 \%$ ash. Of the lipids, fatty acids of the linoleic (18:2) and, to a lesser extent, the linolenic (18:3) series are represented. These may represent a major source of essential fatty acids in inshore waters when the large annual volumes of mucilage released during fragmentation are taken into account. Analysis of protein hydrolysates show that aspartate, glutamate and alanine, all of which occur in the side chains of mucopolypeptides, amount to approximately $68 \%$ of the total spectrum in E. maxima and $50.58 \%$ L. pallida. This may primarily represent protein linkages between polysaccharide side chains in kelp exudates. Sugars amounted to some $6.5-7.1 \%$ of crude dried mucilage from both species (ca $23 \%$ of ash-free dry weight). Of these, acyclic polyol mannitol dominated the ethanol extract accounting for approximately $77 \%$ of the free reducing sugars and polyols present in both kelp species. Alginate accounted for $4.77 \%$ of dried mucilage from E. maxima and $5.01 \%$ in that from L. pallida. Laminarins amounted to $7.23 \%$ by weight of the dried mucilage from E. maxima and $4.59 \%$ in L. pallida when losses in recovery of laminarins are taken into account. Calculation of the energetic contribution of dissolved organic components in kelp mucilage, compared with the measured energetic content, yields $91-95 \%$ recovery if the $6-8 \%$ loss in gravimetric recovery represents organic matter. Energy released as dissolved organic components during kelp fragmentation amounts to approximately $34 \%$ of the total annual energy production of $L$. pallida and $16-17 \%$ of that by E. maxima. Total particulate energy production from both species in a small kelp bed of 700 ha is estimated as $43.25 \times 10^{10} \mathrm{~kJ} \mathrm{y}^{-1}$, whereas that released as dissolved organic matter amounts to $10.74 \times 10^{10}$ $\mathrm{kJy}^{-1}$. This is equivalent to $20.24 \times 10^{7} \mathrm{l}$ mucilage released year ${ }^{-1}$ during fragmentation into the shallow water of the kelp bed, to which should be added undetermined losses of mucilage from the surface of the fronds. Studies of the concentration of dissolved organic matter in the water near a kelp bed suggest that the exudate released during fragmentation is rapidly utilised within $24 \mathrm{~h}$ by microheterotrophic organisms rather than by phytoplankton.
\end{abstract}

\section{INTRODUCTION}

Although a good deal is now known about the chemistry of cell contents and structural components of algae (for reviews, see Von Holdt et al., 1955; Percival, 1968; Craigie, 1974; Mackie and Preston, 1974; Wood 1974; Jensen and Stein, 1978; Stephen, 1979), most studies on the losses of dissolved organic matter by marine macrophytes have been primarily concerned with carbon rather than with analysis of the compo-

\footnotetext{
- Present address: Institute for Marine Environmental Research, Prospect Place, Plymouth, United Kingdom.

- Present address: Lehrkanzel für Meeresbiologie und Ultrastrukturforschung, Währinger Straße 17/VI, A-1090 Wien, Austria.
}

nents which are released into the surrounding water. The values reported for dissolved organic carbon losses by macrophytes are, however, very variable. As much as $30-40 \%$ of fixed carbon has been reported to be released as dissolved organic matter by some macroalgae (Khailov and Burlakova, 1969; Sieburth, 1969), but other studies suggest a lower proportion. Brylinski (1977) reported a value of $1-4 \%$ of total carbon fixed in several species of macroalgae whilst Harlin and Craigie (1975) found only $0.3-1.5 \%$ of photoassimilated carbon released as dissolved organic matter. More recently, Johnston et al. (1977) have calculated a carbon budget for Laminaria saccharina and have shown that out of $100 \mathrm{~g}$ annual input of carbon, approximately $13 \mathrm{~g}_{\text {carbon year }}{ }^{-1}$ is lost as extracellular products whilst a further $10 \mathrm{~g}$ carbon year $^{-1}$ is lost as 
leakage from the tip during fragmentation. Again Hatcher et al. (1977) have estimated that as much as $35 \%$ of the assimilated carbon in Laminaria longicruris is released as dissolved organic material.

It is uncertain at present whether losses over the general surface of the algae are attributable to experimental manipulation and to what extent they occur under natural conditions. Phytoplankton cells, for example, release only from 3-6\% of their assimilated carbon as dissolved organic matter, although higher values of up to $38 \%$ may be released at the end of a bloom when the cells may be undergoing disintegration (Hellebust, 1965; Anderson and Zeutschel, 1970; Ryther et al. 1971; Thomas, 1971; Choi, 1972; Ignatiades, 1973; Berman and Holm-Hansen, 1974). Again Moebus and Johnson (1974) showed that in Ascophyllum nodosum and Fucus vesiculosus, excretion of dissolved organic substances was undetectable except after a period of desiccation (Moebus et al. 1974). Losses of dissolved organic matter associated with fragmentation at the tip of kelp fronds are, however, more predictable and can be related to particulate losses by analysis of the chemical composition of the mucilage and measurement of the wet weight: dry weight ratio of the tissues at the tip of the frond.

The importance of such losses of dissolved organic matter from both macrophytes and phytoplankton in the maintenance of secondary production has been widely recognised (for review, see Sieburth, 1976). Heterotrophic utilisation of dissolved organic matter may play an important part in making dissolved components available in a particulate form for organisms at higher trophic levels and, together with particulate matter released directly by fragmentation of kelp, dominates the primary production of some coastal waters (Mann, 1973; Velimirov et al., 1977; Field et al., 1980; for reviews see Marine Ecology Volume IV: Wangersky, 1978; Conover, 1978; Sorokin, 1978; Newell, 1979). There are, however, no detailed anal yses of the composition of the dissolved organic matter released during fragmentation by kelp, nor of the quantitative significance of such material in coastal waters. The present study was therefore undertaken to analyse the major components of dissolved organic losses during fragmentation of the kelp species Ecklonia maxima and Laminaria pallida, which dominate the shallow waters on the west coast of the Cape Peninsula (South Africa), and to estimate the quantitative significance of such compounds compared with particulate matter released into the water column during the fragmentation process. Our estimates thus represent minimum values for the significance of dissolved organic matter, to which undetermined losses from the surface of the frond, possibly reaching $25-35 \%$ of the photoassimilated carbon, require to be added.

\section{MATERIAL AND METHODS}

\section{Collection of Samples}

Samples of material from the kelps Ecklonia maxima and Laminaria pallida were removed by cutting the stipe below the meristematic zone following collection in March 1979 from a depth of approximately 0-5 m at Oudekraal on the west coast of the Cape Peninsula, South Africa. The material was then brought ashore and the eroding tips removed from approximately 50 fronds. A second sample of frond from below the eroding zone at the tip was removed, and a final samples, removed from the meristematic zone together with the upper part of the stipe. Material from each of the three zones was placed in a polythene bag on ice and transported to the laboratory. The whole bag was then placed in a deep-freeze for up to $4 \mathrm{~d}$ prior to use.

The frozen material was cut into small pieces and placed in a covered glass funnel and the mucilage including cell contents allowed to drain into a sealed beaker overnight at $16^{\circ} \mathrm{C}$. The following morning at least 10 samples of approximately $10 \mathrm{ml}$ of mucilage from each of the three zones from both species were placed in preweighed clean glass vials and frozen in liquid nitrogen. They were then placed on a freeze dryer until dry, reweighed and the contents ground to a fine powder with a glass rod.

\section{Analysis of the Dried Samples}

The 60 dried samples obtained from the two kelp species were then analysed for carbohydrates, proteins and lipids. Ash-free dry weight was determined using a muffle furnace at $450^{\circ}$ for $12 \mathrm{~h}$. The volumes and concentrations of the mucilage were then related to particulate losses from the eroding tips by measurement of the wet weight: dry weight ratio of the original kelp.

\section{Total Carbohydrate, Protein and Lipid}

Total carbohydrate, protein and lipid in the dried samples were measured using the methods of Holland and Gabbott (1971) and Holland and Hannant (1973). A weighed sample of $2-3 \mathrm{mg}$ was homogenised in $500 \mu \mathrm{l}$ water. The homogenate was then split into three samples. One sample was treated with cold $15 \%$ trichloracetic acid to precipitate protein. Part of the supernatant was then used to determine free reducing sugars by ferricyanide reduction (Folin and Malmros, 1929); the other part after acid hydrolysis was used to 
determine the total carbohydrate. The protein precipitated by $\mathrm{TCA}$ was digested at $56^{\circ} \mathrm{C}$ with $\mathrm{N} \mathrm{NaOH}$ centrifuged and the protein in the supernatant determined by Folin-Ciocalteau reagent (Lowry et al., 1951). The second homogenate sample was digested for 30 min at $56^{\circ} \mathrm{C}$ with $5 \mathrm{~N} \mathrm{NaOH}$, centrifuged and the supernatant was determined to give total protein. The third sample was extracted with chloroform-methanol which was then made biphasic with added water to remove non-lipids. The chloroform phase was evaporated at $100^{\circ} \mathrm{C}$ and a part redissolved in pure chloroform and then re-evaporated. The quantity of total lipid in this sample was obtained by charring with sulphuric acid in comparison with a tripalmitan standard (Marsh and Weinstein, 1966). The other part of the extract was treated with activated silicic acid which removed phospholipid. The remaining neutral lipid was then also determined against a triplamitan standard. All results were expressed both in terms of the ash-free and crude dry weight of the powdered samples of mucilage.

\section{Component Carbohydrates}

\section{Monosaccharides and Polyols}

The sugars which are in the mucilage comprise a mixture of monosaccharides and more complex sugars, some of which may be strongly bound to structural components such as laminarins and alginates (for reviews see Mackie and Preston, 1974; Jensen and Stein, 1978). Monosaccharides and polyols may be extracted by reflux in $200 \mathrm{ml} 80 \%$ ethanol for $2-3 \mathrm{~h}$ (Holligan and Drew, 1971), but long-chain polysaccharide sugars require extensive hydrolysis, in sealed glass tubes to minimise sugar oxidation, in approximately $3 \mathrm{ml} 2 \mathrm{~N}$ trifluoracetic acid (TFA) for up to $24 \mathrm{~h}$ (Sweeley et al., 1963; Adams, 1965; Björndal et al., 1970). Alginates and laminarins were assayed separately in separate pooled dried samples of mucilage from Ecklonia maxima and Laminaria pallida.

Sugars in both the ethanol soluble extract and the TFA hydrolysate were identified by descending paper chromatography. A few drops of distilled water were added to a freeze-dried sample of each extract. A spot of the concentrated extract was then placed on Whatman No. 1 paper from a capillary tube and reference sugars made up in distilled water were run with the sample. Polyols in the ethanol soluble fraction were resolved using butanol, acetic acid and water in the ratio $2: 1: 1$ and the chromatogram was visualised as black spots after approximately $12 \mathrm{~h}$ by spraying with freshly-prepared Tollen's reagent $15 \%$ ammoniacal $\mathrm{AgNO}_{3}, 5 \mathrm{M}$ aqueous $\mathrm{NH}_{3}$ plus $0.1 \mathrm{M} \mathrm{AgNO}_{3}$ in equal volumes) and heating for 5-10 min. The acid hydrolysate was run using a solvent of ethyl acetate, pyridine and water in the ratio of $8: 2: 1$ by volume, the hexose sugar positions being identified after approximately 12 $\mathrm{h}$ by spraying with $3 \% \mathrm{p}$-anisidine hydrochloride in 1 butanol and heating at $105^{\circ} \mathrm{C}$ for $10 \mathrm{~min}$. The sugars then gave yellow fluorescence under U/V light (see also Lewis and Smith, 1967a, b).

In order to assay the component sugars quantitatively, the ethanol soluble sample was dried on a rotary evaporator, washed to the bottom of the flask with distilled water together with an internal standard of $500 \mu$ l erythritol $(100 \mathrm{mg}$ per $100 \mathrm{ml}$ distilled water). frozen and freeze-dried. The hydrolysate was dried on a rotary evaporator, washed in Analar methanol to form the volatile methyl ester of TFA, and redried. The internal standard of $500 \mu \mathrm{l}$ erythritol was then added and the sample freeze-dried as in the ethanol soluble fraction above. The residue from the $24 \mathrm{~h}$ hydrolysis was then re-hydrolysed in sealed tubes in approximately $3 \mathrm{ml}$ of $2 \mathrm{~N} \mathrm{TFA}$ and the hydrolysate recovered and dried with an internal standard as before.

The freeze-dried samples together with their internal standards were then derivatised prior to analysis of the component sugars with a Pye-Unicam Series 104 Chromatograph. A sample of $850 \mu$ l anhydrous pyridine was added to each stoppered flask together with $100 \mu \mathrm{l}$ hexamethyldisilazane (HMDS) and $50 \mu \mathrm{l}$ trimethylchlorosilane (TMS) and the contents left to derivatise for $3 \mathrm{~h}$ at room temperature. The contents were then transferred into stoppered tubes and centrifuged at $800 \times \mathrm{g}$ for $10 \mathrm{~min}$. Standards of the following known sugars were made up to $0.2,0.4,0.6,0.8$ and $1.0 \mathrm{mg} \mathrm{ml}^{-1}$ from stock solutions containing $100 \mathrm{mg}$ $\mathrm{ml}^{-1}$ : fucose, xylose, galactose, mannose, glucose, mannitol, rhamnose, arabinose and erythritol. A sample of $500 \mu$ l of the stock erythritol was added to each of the sugars as an internal standard. These standard solutions were then freeze-dried and derivatised as described above. All samples were analysed within 12 $\mathrm{h}$ of derivatisation.

Samples of $10 \mu \mathrm{l}$ were injected into the column which contained diatomite calcium as a solid support coated with $2 \%$ SE 52 as a non-polar liquid phase. The flow rate of the carrier gas $\left(\mathrm{N}_{2}\right)$ was $30 \mathrm{ml} \mathrm{min}{ }^{-1}$. Samples were injected at $140^{\circ} \mathrm{C}$ and the temperature ran isothermally for $4 \mathrm{~min}$, after which it increased from $140^{\circ}$ to $320^{\circ} \mathrm{C}$ at $6^{\circ} \mathrm{C} \mathrm{min}{ }^{-1}$ (see Holligan, 1971 ; Holligan and Drew, 1971). The relative retention time of each sugar is commonly calculated from the sugar distance $(\mathrm{cm})$ relative to the position of an internal standard of erythritol. In practice, the erythritol distance is rather variable, whereas the retention time of mannitol is much more constant. We have therefore calculated the ratio between the mean of all the eryt- 
Table 1. Values for intercept (a), slope (b) and coefficient of variation $\left(r^{2}\right)$ for regression lines relating sugar concentration $(\mu \mathrm{g} \quad Y)$ to peak areas (height $x$ retention time, $X$ ) for standard sugars and mannitol. Equation for the regression, $Y=a+b \cdot x$

\begin{tabular}{lcccc}
\hline Sugar & $\begin{array}{c}\text { Retention time } \\
\text { (min) }\end{array}$ & $a$ & $b$ & $r^{2}$ \\
\hline$\alpha$-Mannose & 3.896 & 0.58 & 0.98 & 0.97 \\
$\alpha$-Rhamnose & 4.204 & 0.30 & 1.06 & 0.99 \\
Arabinose & 4.276 & 0.27 & 0.86 & 0.99 \\
$\alpha$-Galactose & 4.294 & 0.51 & 1.88 & 0.98 \\
$\alpha$-Glucose & 4.452 & 1.48 & 0.63 & 0.99 \\
$\beta$-Mannose & 4.470 & 2.94 & 0.75 & 0.91 \\
$\beta$-Galactose & 4.550 & 0.94 & 1.03 & 0.98 \\
$\beta$-Rhamnose & 4.636 & 1.28 & 1.72 & 0.91 \\
$\alpha$-Fucose & 4.674 & 0.48 & 1.48 & 0.98 \\
$\alpha$-Xylose & 4.898 & 0.73 & 1.34 & 1.00 \\
$\beta$-Fucose & 4.938 & 1.45 & 0.70 & 0.96 \\
$\beta$-Glucose & 4.964 & 2.13 & 0.42 & 0.98 \\
Mannitol & 5.264 & 0.67 & 0.98 & 0.28 \\
\hline
\end{tabular}

hritol distances and that of mannitol and subsequently normalised the internal standard erythritol distance against that of the identified mannitol peak. The peak heights of all sugars were also corrected relative to a mean value for the peak height of the internal erythritol standard. The concentration of each sugar could then be calculated from the peak area (relative retention time $\times$ peak height) using the equations for the regressions for the sugar standard shown in Table 1.

\section{Alginates and Laminarins}

Alginates were assayed gravimetrically by a method adapted from several sources based essentially on that described by Haug (1965; see also Chapman, 1950; McDowell, 1973; Lewin, 1974). A weighed sample of approximately $400 \mathrm{mg}$ of dried mucilage was dissolved in approximately $10 \mathrm{ml} 5 \% \mathrm{Na}_{2} \mathrm{CO}_{3}$ to form soluble sodium alginate. $10 \mathrm{ml}$ of $5 \% \mathrm{CaCl}_{2}$ was then added to the filtered solution to form a white cloud of precipitating calcium alginate and calcium carbonate. The precipitate was sedimented by centrifugation for 10 min at $800 \times \mathrm{g}$. The supernatant was then removed and added to a further $10 \mathrm{ml} 5 \% \mathrm{CaCl}_{2}$, centrifuged, and the supernatant discarded. $50 \mathrm{ml}$ of $5 \% \mathrm{HCl}$ was added to the combined sediments and left overnight. The precipitated alginic acid was then sedimented by centrifugation at $800 \times \mathrm{g}$ for $10 \mathrm{~min}$ and transferred in $2 \mathrm{ml} 5 \% \mathrm{HCl}$ onto a preweighed $0.54 \mu \mathrm{m}$ Sartorius cellulose acetate membrane filter and dried to constant weight at $60^{\circ} \mathrm{C}$. The gravimetric recovery of a weighed sample of approximately $400 \mathrm{mg}$ of alginic acid (Sigma) was found to be $92.64 \%$ using this serni-micro modification of the procedure for estimation of alginate.

Laminarins were assayed gravimetrically by a method outlined by Elyakova and Zvyagintseva (1974). A weighed sample of $0.5-1.0 \mathrm{~g}$ of dried mucilage was washed free of pigments for $1 \mathrm{~h}$ with $10 \mathrm{ml}$ cold $100 \%$ methanol and centrifuged at $800 \times \mathrm{g}$ for $10 \mathrm{~min}$. The supernatant was discarded and the sediment extracted with $10 \mathrm{ml} 0.4 \% \mathrm{HCl}$ once at room temperature for $4 \mathrm{~h}$ and once at $50{ }^{\circ} \mathrm{C}$ for $5 \mathrm{~h}$. The extracts were precipitated with $30 \mathrm{ml}$ methanol : 1-butanol (3:1) with subsequent re-precipitation of the residues. The precipitate was sedimented by centrifugation at $80 \times \mathrm{g}$ for $10 \mathrm{~min}$ and dissolved in $20 \mathrm{ml}$ distilled water. The aqueous solution was then treated with $1 \mathrm{ml} 0.5 \mathrm{M}$ Cetavlon (cetyl-trimethyl ammonium bromide) until precipitation of the acidic polysaccharide material was complete. The laminarin in the supernatant was then precipitated with a further $30 \mathrm{ml}$ methanol : l-butanol (3:1), filtered under vacuum onto preweighed $0.54 \mu \mathrm{m}$ Sartorius cellulose acetate paper, oven dried at $60^{\circ} \mathrm{C}$ and weighed.

The percentage gravimetric recovery using this method was determined by analysis of a known mixture of approximately $400 \mathrm{mg}$ alginic acid (Sigma) and $400 \mathrm{mg}$ Iaminarin (Koch-Light). It was found that the alginic acid was not completely precipitated by treatment with Cetavlon, $1.83 \%$ being left in the supernatant, whilst only $82.4 \%$ of the laminarin was precipitated by treatment of the supernatant with methanol : l-butanol. Accordingly, we have adjusted the figures for laminarin shown on p. 54 and Table 9 to account for a loss of approximately $17 \%$ in recovery.

\section{Protein Hydrolysate Analysis}

A weighed sample of dried mucilage was hydrolysed in $1 \mathrm{ml}$ of $5.7 \mathrm{~N} \mathrm{HCl}$ at $110^{\circ} \mathrm{C}$ for $24 \mathrm{~h}$. Oxygen was 
Table 2. Laminaria pallida. Protein hydrolysate analysis of a 4.013-mg sample of dried mucilage. Values show nanomoles recovered from a normal mucilage sample and from one to which $500 \mathrm{nM}$ of the appropriate amino acid had been added. Losses following acid hydrolysis are calculated from actual recovery from the enriched sample compared with that anticipated from the sum of $500 \mathrm{nM}$ plus that in the normal mucilage sample

\begin{tabular}{|c|c|c|c|}
\hline Hydrolysate & $\begin{array}{l}\text { Nanomoles } \\
\text { recovered } \\
\text { from } \\
\text { mucilage }\end{array}$ & $\begin{array}{c}\text { Nanomoles } \\
\text { recovered from } \\
\text { mucilage plus } \\
500 \mathrm{nM} \text { of } \\
\text { appropriate component }\end{array}$ & $\begin{array}{l}\% \text { loss of re- } \\
\text { covery of } 500 \mathrm{nM} \\
\text { following acid } \\
\text { hydrolysis }\end{array}$ \\
\hline \multicolumn{4}{|c|}{ Basic Components } \\
\hline Lysine & 17.13 & 461.65 & 1.12 \\
\hline Histidine & 0.00 & 453.02 & 9.40 \\
\hline Unknown & 308.70 & (none 285.70 added) & 7.45 \\
\hline $\mathrm{NH}_{3}$ & 264.40 & 803.71 & GAIN 5.00 \\
\hline Arginine & 17.52 & 467.26 & 9.71 \\
\hline \multicolumn{4}{|c|}{ Acidic Components } \\
\hline Threonine & 25.05 & 467.69 & 10.92 \\
\hline Serine & 31.28 & 445.24 & 16.19 \\
\hline Glutamate & 140.29 & 624.52 & 2.47 \\
\hline Proline & 22.65 & 481.05 & 7.96 \\
\hline Glycine & 48.28 & 506.51 & 7.62 \\
\hline Alanine & 375.50 & 849.28 & 2.99 \\
\hline Cystine & 0.00 & 440.77 & 11.85 \\
\hline Valine & 19.84 & 480.91 & 7.48 \\
\hline Methionine & 6.81 & 483.45 & 4.60 \\
\hline Isoleucine & 9.17 & 467.44 & 8.21 \\
\hline Leucine & 16.02 & 478.44 & 7.29 \\
\hline Tyrosine & 4.00 & 463.15 & 8.10 \\
\hline Phenylalanine & 10.76 & 472.69 & 7.46 \\
\hline
\end{tabular}

expelled from the hydrolysis tubes by repeated flushing with nitrogen followed by evacuation to $0.02 \mathrm{~mm}$ $\mathrm{Hg}$. A sample of $50 \mu \mathrm{l}$ of $5 \%$ solution of phenol in distilled water was added to each tube to improve recovery of tyrosine. Analysis of the protein hydrolysate was based on the method of Spackman et al. (1958) using a double column amino acid analyser (Beckman Model 118) in which acidic and neutral components are separated on a long column and basic components on a short column. An intemal standard of AGP ( homologue of arginine) was used in all assays.

Both destruction during acid hydrolysis and interference by mannitol may reduce the recovery of labile amino acids. Fong and O'Dor (1979) have recently reported that interactions between mannitol and a number of amino acids may interfere in the chromatographic analysis of other amino acids, the recovery of which may then be directly or inversely proportional to the amount of D-mannitol present in a protein sample before acid hydrolysis. We have estimated the losses in recovery through these possible sources by comparison of the values obtained following analysis of normal

- Standard Hydrolysate Analysis on Models 118 and 119. Beckman Instruments (Spinco Division). A-TP-068. Dec. 1973. mucilage samples and ones to which $500 \mathrm{nM}$ of standard amino acids had been added. The minimum value of each amino acid which should be recovered from the latter is then given by the sum of $500 \mathrm{nM}$ plus that in the normal sample. Comparison of this figure with the actual recovery obtained from the enriched sample then gives a measure of losses in recovery of $500 \mathrm{nM}$ of each amino acid following acid hydrolysis in the presence of mannitol.

The results are summarised in Table 2 which shows that losses generally amount to approximately $7 \%$ but, in the case of serine, may reach $16 \%$. The relative significance of destruction of labile amino acids during hydrolysis and interference effects of mannitol was not determined, but it is significant that a $5 \%$ gain in ammonia was obtained. This suggests that destruction of amino acids during hydrolysis plays a significant part in the losses recorded and that at the concentration of mannitol in the mucilage samples, interference is not a factor which dominates the recovery of labile amino acids in the hydrolysate. Fong and O'Dor (1979) reported a decrease in the recovery of glutamate from $16.7 \%$ of the total amino acids by weight in a sample of albumin with no D-mannitol added, to only $5.5 \%$ in the presence of $90 \% \mathrm{D}$-mannitol. Total sugars in our dried mucilage samples amounted to approximately 
Table 3. Ecklonia maxima and Laminaria pallida. Major biochemical components in a mixed sample of $4283 \mathrm{mg}$ dried mucilage. Each value is the mean of three estimations

\begin{tabular}{|ccccccccc}
\hline A.mount & $\begin{array}{c}\text { Total } \\
\text { lipid }\end{array}$ & $\begin{array}{c}\text { Neutral } \\
\text { lipid }\end{array}$ & Phospholipid & $\begin{array}{c}\text { Total } \\
\text { carbohydrate }\end{array}$ & $\begin{array}{c}\text { Free reducing } \\
\text { sugars }\end{array}$ & $\begin{array}{c}\text { Polysaccharides } \\
\text { Total } \\
\text { protein }\end{array} \begin{array}{c}\text { TCA } \\
\text { protein }\end{array}$ \\
\hline $\mathrm{mg}$ & 0.014 & 0.016 & - & 0.502 & 0.32 & 0.189 & 0.155 \\
$\%$ & 0.29 & 0.33 & - & 10.39 & 6.47 & 3.92 & 3.21 \\
2.41 & \\
\hline
\end{tabular}

$23 \%$ of the ashfree dry weight only (see p. 53), of which some $60-70 \%$ is represented by mannitol. It seems likely, therefore, that although mannitol interference may be of significance at higher concentrations than occur in our samples, the recorded loss in recovery of some $5-7 \%$ can be regarded as a normal reflection of destruction during acid hydrolysis.

\section{Lipids}

Lipids were extracted from $1.5-2.0 \mathrm{~g}$ freeze-dried mucilage with chloroform-methanol-water by the method of Bligh and Dyer (1959) and weighed on a microbalance. Lipid classes were identified by thin layer chromatography on silica gel G using diethyl etherhexane-acetic acid (15:81:1) and visualised by charring with chromic acid, prepared by dissolving $0.6 \mathrm{~g}$ potassium dichromate in $50 \mathrm{ml}$ water. The plates were then sprayed to an even faint yellow colour and held at $18^{\circ} \mathrm{C}$ for approximately $8 \mathrm{~min}$. The charred plates were read on a Vitatron densitometer using a wavelength of $489 \mu \mathrm{m}$ with a $0.25 \mathrm{~cm}$ slit width.

Lipids extracted from the freeze dried sample were also analysed for total fatty acid composition by gas liquid chromatography on $6 \%$ DEGS (diethylene glycol succinate) using 100-120 mesh Chromosorb $W$ as support (Spark and Louw, 1973). The extract was first methylated for 3 min with $15 \%$ boron trifluoride in methanol (Metcalfe et al. 1966). Each sample was run in duplicate. Accuracy of the GLC was indicated as $0.1 \%$. The signal output from the flame detector was processed on a HP 3352 laboratory data system.

\section{RESULTS}

\section{Total Lipid, Protein and Carbohydrate Content of Mucilage}

In the first instance it was necessary to determine the gross biochemical composition of mucilage from kelp. Such data indicated which major components required more detailed analysis and also served to verify the quantitative results obtained by other methods. The results of an analysis of a mixed sample of dried mucil- age from Ecklonia maxima and Laminaria pallida are summarised in Table 3.

Lipid values were very low and the concentrations recorded were at the lower limit of detectability by this method. Partly for this reason neutral lipid values were $0.33 \%$ of the dried mucilage whereas a total lipid value of only $0.29 \%$ was obtained. No phospholipids were recorded in the sample. In contrast, total carbohydrate values were as high as $10.39 \%$ of the dried mucilage, comprising some $6.5 \%$ free reducing sugars and $3.9 \%$ polysaccharides. Total proteins reached $3.21 \%$ of which TCA precipitated material accounted for $2.41 \%$. it seems, then, that the mucilage from kelp is likely to contain some $10 \%$ carbohydrates, $3 \%$ protein and approximately $0.3 \%$ lipids per unit dried weight. Each of these major components, as well as laminarins and alginates were subsequently analysed in more detail and the summed results used to calculate the energetic significance of dissolved organic matter released during fragmentation of kelp.

\section{Analysis of Lipids}

The major lipid classes in samples of mucilage from the stem plus meristem, frond and eroded fronds of both Ecklonia maxima and Laminaria pallida are shown in Table 4. There is evidently considerable variability in the proportions of major lipid classes in the eroded fronds. The highest values recorded in the latter resemble those found in mucilage from other parts of the plant whereas in other samples a loss of lipid had already occurred from the mucilage in the eroding tip before the samples were taken for analysis. In both E. maxima and L. pallida, however, the average lipid content was $0.17-0.18 \%$ of the dried weight of the mucilage sample. The significance of this value in the energetic contribution of kelp exudates to the primary production of nearshore water is discussed on p. 54 .

The percentage fatty acid composition of lipids in mucilage from Ecklonia maxima and Laminaria pallida is shown in Table 5 (see also Velimirov, 1979). In common with many phytoplankters and animals, the most important fatty acids are palmitic (16:0), stearic 
(18:0), palmitoleic (16:1), oleic (18:1) and linoleic (18:2). There is also an important component of long chain (>C 20) fatty acids which has not been identified in this study but which may represent a 20:5 fatty acid (see Holland, 1978).

It is of some significance that fatty acids of the linoleic (18:2), and to a lesser extent the linolenic (18:3), series are present in the kelp mucilage. As pointed out by Guarnieri and Johnson (1970), and Sinnhuber et al. (1972; see also Holland, 1978), fish and other organisms including zooplankton (see Lee and Barnes, 1975) may be unable to synthesise these two fatty acids which are required for structural and physiological purposes and are thus essential dietary components in such animals. Ackman et al. (1968) and Watanabe and Ackmann (1972; for review, see Holland, 1978) have suggested that phytoplankton may provide a source of such substances to consumer organisms. It will be shown later, however, that the release of such components, even in low concentrations during fragmentation of kelp, may represent a major source of essential fatty acids in nearshore water when the large annual volume of mucilage released during fragmentation is taken into account.

Table 4. Ecklonia maxima and Laminaria pallida. Analysis of lipids in mucilage. Total lipid expressed as percentage of dried mucilage, lipid classes as percentage of total lipid

\begin{tabular}{|c|c|c|c|c|c|c|c|c|c|}
\hline \multirow{4}{*}{$\begin{array}{l}\text { Lipid class } \\
\text { Polar lipid }\end{array}$} & \multicolumn{9}{|c|}{ Source of mucilage } \\
\hline & \multicolumn{4}{|c|}{ Ecklonia maxima } & \multicolumn{5}{|c|}{ Laminaria pallida } \\
\hline & \multirow{2}{*}{$\begin{array}{c}\begin{array}{c}\text { Stem and } \\
\text { meristem }\end{array} \\
10.0\end{array}$} & \multirow{2}{*}{$\begin{array}{c}\text { Frond } \\
8.3\end{array}$} & \multicolumn{2}{|c|}{$\begin{array}{l}\text { Eroded } \\
\text { frond }\end{array}$} & \multicolumn{2}{|c|}{$\begin{array}{l}\text { Stem and } \\
\text { meristem }\end{array}$} & \multicolumn{2}{|c|}{ Frond } & $\begin{array}{c}\text { Eroded } \\
\text { frond }\end{array}$ \\
\hline & & & 12.0 & 12.7 & 18.4 & 17.2 & 16.6 & 19.2 & 13.6 \\
\hline Unknown" & 7.2 & 23.4 & & 9.7 & 26.3 & 23.7 & 6.7 & - & \\
\hline Monoglyceride & 5.2 & 8.3 & 10.4 & 9.7 & 6.6 & 7.1 & 5.1 & - & 5.7 \\
\hline Cholesterol/sterol & 7.6 & 11.0 & 3.3 & 9.7 & 12.5 & 13.0 & 8.9 & 13.2 & 7.3 \\
\hline Alcohol & 4.1 & - & - & - & - & - & - & - & - \\
\hline Free fatty acid & 12.6 & 26.8 & 11.2 & 37.6 & 23.0 & 21.3 & 15.4 & 28.8 & 17.9 \\
\hline Triglyceride & 41.8 & 22.6 & 5.8 & 20.6 & 13.2 & 17.8 & 30.2 & 13.2 & 23.9 \\
\hline Methyl ester & - & - & - & - & - & - & - & - & - \\
\hline Wax ester & 5.2 & trace & 2.5 & trace & trace & trace & 4.4 & trace & 6.5 \\
\hline Hydrocarbons & 6.1 & trace & $54.8^{+}$ & trace & trace & trace & 12.9 & trace & $25.1^{+}$ \\
\hline \multirow[t]{2}{*}{ Total Lipids } & 0.35 & 0.05 & 0.06 & 0.23 & 0.13 & 0.16 & 0.15 & 0.11 & 0.36 \\
\hline & \multicolumn{4}{|c|}{$\bar{x}=0.173$} & \multicolumn{5}{|c|}{$\bar{x}=0.182$} \\
\hline
\end{tabular}

Table 5. Ecklonia maxima and Laminaria pallida. Relative percentage fatty acid composition of lipids in mucilage

\begin{tabular}{|c|c|c|c|c|c|c|c|}
\hline \multirow{3}{*}{$\begin{array}{l}\text { Lipid } \\
\text { class }\end{array}$} & \multirow{3}{*}{$\begin{array}{l}\text { Fatty } \\
\text { acid }\end{array}$} & \multicolumn{6}{|c|}{ Source of mucilage } \\
\hline & & \multicolumn{3}{|c|}{ Ecklonia maxima } & \multicolumn{3}{|c|}{ Laminaria pallida } \\
\hline & & $\begin{array}{l}\text { Stem and } \\
\text { meristem }\end{array}$ & Frond & $\begin{array}{l}\text { Eroded } \\
\text { frond }\end{array}$ & $\begin{array}{l}\text { Stem and } \\
\text { meristem }\end{array}$ & Frond & $\begin{array}{c}\text { Eroded } \\
\text { frond }\end{array}$ \\
\hline \multicolumn{8}{|l|}{ Saturated } \\
\hline Myristic & $14: 0$ & 3.28 & 3.28 & 8.76 & 2.14 & 7.30 & 4.40 \\
\hline Palmitic & $16: 0$ & 20.41 & 17.65 & 5.19 & 12.31 & 29.04 & 23.03 \\
\hline Stearic & $18: 0$ & 7.24 & 6.61 & 0.47 & 3.96 & 6.82 & 7.90 \\
\hline \multicolumn{8}{|l|}{ Monoenes } \\
\hline Palmitoleic & $16: 1$ & 5.77 & 6.95 & 0.60 & 6.93 & 10.31 & 8.16 \\
\hline Oleic & $18: 1$ & 24.07 & 23.83 & 8.28 & 18.97 & 21.36 & 24.82 \\
\hline Gadoleic & $20: 1$ & 1.96 & 5.05 & 1.85 & 7.35 & 2.47 & 1.97 \\
\hline \multicolumn{8}{|l|}{ Polyunsaturated } \\
\hline Linoleic & $18: 2$ & 8.53 & 6.36 & 1.18 & 5.00 & 3.14 & 7.02 \\
\hline Linolenic & $18: 3$ & 0.60 & 0.43 & 0.38 & 1.33 & 0.85 & 0.66 \\
\hline Unidentified long chain & $>20$ & 24.31 & 20.00 & 69.7 & 24.16 & 11.81 & 16.11 \\
\hline Other short chain & $<20$ & 3.83 & 10.27 & 3.59 & 17.85 & 6.9 & 5.93 \\
\hline
\end{tabular}


Table 6. Ecklonia maxima. Summarised analysis of protein hydrolysate of mucilage. Data expressed as percentage by weight of dried mucilage

\begin{tabular}{|c|c|c|c|}
\hline Hydrolysate & $\begin{array}{l}\text { Stem and } \\
\text { meristem }\end{array}$ & Frond & $\begin{array}{l}\text { Eroded } \\
\text { frond }\end{array}$ \\
\hline \multicolumn{4}{|l|}{ Basic components } \\
\hline Tryptophan & 0.014 & 0.011 & 0.00 \\
\hline Lysine & 0.049 & 0.062 & 0.079 \\
\hline Histidine & 0.016 & 0.017 & 0.022 \\
\hline $\mathrm{NH}_{3}$ & 0.133 & 0.150 & 0.168 \\
\hline Arginine & 0.067 & 0.055 & 0.062 \\
\hline \multicolumn{4}{|l|}{ Acidic components } \\
\hline Aspartate & 1.033 & 0.553 & 0.418 \\
\hline Threonine & 0.643 & 0.070 & 0.077 \\
\hline Serine & 0.087 & 0.087 & 0.098 \\
\hline Glutamate & 1.216 & 1.068 & 1.108 \\
\hline Proline & 0.076 & 0.102 & 0.184 \\
\hline Glycine & 0.062 & 0.068 & 0.090 \\
\hline Alanine & 0.991 & 0.933 & 0.946 \\
\hline Cystine & 0.152 & 0.039 & - \\
\hline Valine & 0.045 & 0.056 & 0.077 \\
\hline Methionine & 0.055 & 0.023 & 0.298 \\
\hline Isoleucine & 0.023 & 0.036 & 0.054 \\
\hline Leucine & 0.033 & 0.052 & 0.077 \\
\hline Tyrosine & 0.020 & 0.055 & 0.057 \\
\hline Phenylalanine & 0.027 & 0.017 & 0.105 \\
\hline Total $\%$ & 4.742 & 3.454 & 3.92 \\
\hline $\begin{array}{l}\text { Asparate, glutamate } \\
\text { and alanine } \\
\text { as } \% \text { of total }\end{array}$ & 68 & 73 & 63 \\
\hline
\end{tabular}

\section{Analysis of Protein Hydrolysate}

The major components following chromatographic analysis of amino acids in hydrolysates of mucilage from the stem plus ineristem, frond and eroded fronds of Ecklonia maxima and Laminaria pallida are shown in Tables 6 and 7 . Apart from a absence of histidine, and the occurrence of an unknown substance (possibly an acid derivative of lysine) in mucilage from $L$. pallida, the amino acid spectra are similar in both kelp species. Aspartate, glutamate and alanine, all of which are amino acids in the side chains of mucopolypeptides, amount to approximately $68 \%$ of the total spectrum in E. maxima and $50.35 \%$ in L. pallida. These may primarily represent protein linkages between polysaccharide chains in the kelp exudates (Rogers and Perk, 1968).

No correction has been made for the losses in recovery of up to $10 \%$ of amino acids following acid hydolysis (p. 49). Nevertheless it is evident that derivatives including $\mathrm{NH}_{3}$ amount to some $5 \%$ of the dry weight of mucilage in the meristematic zone of both Ecklonia maxima and Laminaria pallida and that a decline occurs in the mucilage taken from the frond and erod- ed tips. In both species, amino acids amounted to some $3-3.5 \%$ of the mucilage from the frond, but values were more variable in samples from the eroding tips ranging from $3.9 \%$ in E. maxima to only $1.9 \%$ in $L$. pallida. As in the case of lipids, this variability no doubt reflects the extent of losses which had occurred from the frond prior to sampling. The maximal value of approximately $5 \%$ of the dry weight of the mucilage has therefore been used in a calculation of the energetic contribution of protein to the exudate following fragmentation of kelp (p. 54).

\section{Analysis of Sugars}

The component sugars in ethanol extracts of dried mucilage and following hydrolysis of the residue for up to $24 \mathrm{~h}$ in $2 \mathrm{~N}$ trifluoracetic acid were resolved by paper chromatography. The derivatised samples were subsequently assayed quantitatively by gas liquid chromatography as described on $\mathrm{p} .47$. The results are summarized in Table 8.

Total sugars and soluble carbohydrate amounted to some $6.5-7.1 \%$ of the crude dried mucilage from both Ecklonia maxima and Laminaria pallida (approxi-

Table 7. Laminaria pallida. Summarised analysis of protein hydrolysate of mucilage. Data expressed as percentage by weight of dried mucilage. The unknown amino acid may be an acid derivative of lysine

\begin{tabular}{|lccc|}
\hline Hydrolysate & $\begin{array}{c}\text { Stem and } \\
\text { meristem }\end{array}$ & Frond & $\begin{array}{c}\text { Eroded } \\
\text { frond }\end{array}$ \\
\hline Basic components & & & \\
Tryptophan & 0.0016 & - & - \\
Lysine & 0.059 & 0.053 & 0.061 \\
Unknown & 1.522 & 0.947 & 0.260 \\
NH & 0.213 & 0.108 & 0.094 \\
Arginine & 0.064 & 0.065 & 0.054 \\
Acidic components & & & \\
Aspartate & 1.044 & 0.430 & 0.200 \\
Threonine & 0.086 & 0.060 & 0.056 \\
Serine & 0.097 & 0.065 & 0.053 \\
Glutamate & 1.088 & 0.433 & 0.349 \\
Proline & 0.063 & 0.053 & 0.049 \\
Glycine & 0.093 & 0.067 & 0.003 \\
Alanine & 0.680 & 0.638 & 0.396 \\
Cystine & 0.009 & - & - \\
Valine & 0.075 & 0.047 & 0.062 \\
Methionine & 0.021 & 0.021 & 0.032 \\
Isoleucine & 0.044 & 0.025 & 0.059 \\
Leucine & 0.055 & 0.043 & 0.062 \\
Tyrosine & 0.023 & 0.016 & 0.041 \\
Phenylalanine & 0.034 & 0.038 & 0.056 \\
Total \% & 5.27 & 3.107 & 1.887 \\
Aspartate, gluta- & & & \\
mate and alanine & 53.35 & 48.31 & 50.08 \\
as\% of total & & & \\
\hline
\end{tabular}


mately $23 \%$ of the ash-free dry weight). Of these, the acyclic polyol mannitol dominated the ethanol extract, accounting for approximately $77 \%$ of the total free reducing sugars plus polyols present in both kelp species (Table 8). Mannitol is a primary photosynthate and major translocatory carbohydrate whose presence has been recorded in many algae including Laminaria, but which is absent from the extracellular dissolved organic matter released from phytoplankton (for reviews see Von Holdt et al. 1955; Percival, 1968;
Craigie, 1974; Mackie and Preston, 1974; Stephen, 1979). There were also small but variable quantities of unidentified compounds of large molecular weight which appeared in the ethanol extract and which had longer retention times than mannitol. These may represent mannitol glycosides formed from partial TMS derivatives of laminarin glycosyl units.

The sugars extracted by acid hydrolysis represent liberated components of carbohydrates of larger molecular weight and comprise principally the aldose

Table 8. Ecklonia maxima and Laminaria pallida. Analysis of sugars and mannitol in up to 4 samples of mucilage from the stem plus meristem, frond and eroded fronds. Percentage of sugars plus mannitol in mucilage expressed as g ${ }^{-1} \mathrm{dry}_{\text {weight }}$ and $\mathrm{g}^{-1}$ ashfree dry weight. Relative proportion of mannitol expressed as percentage of total

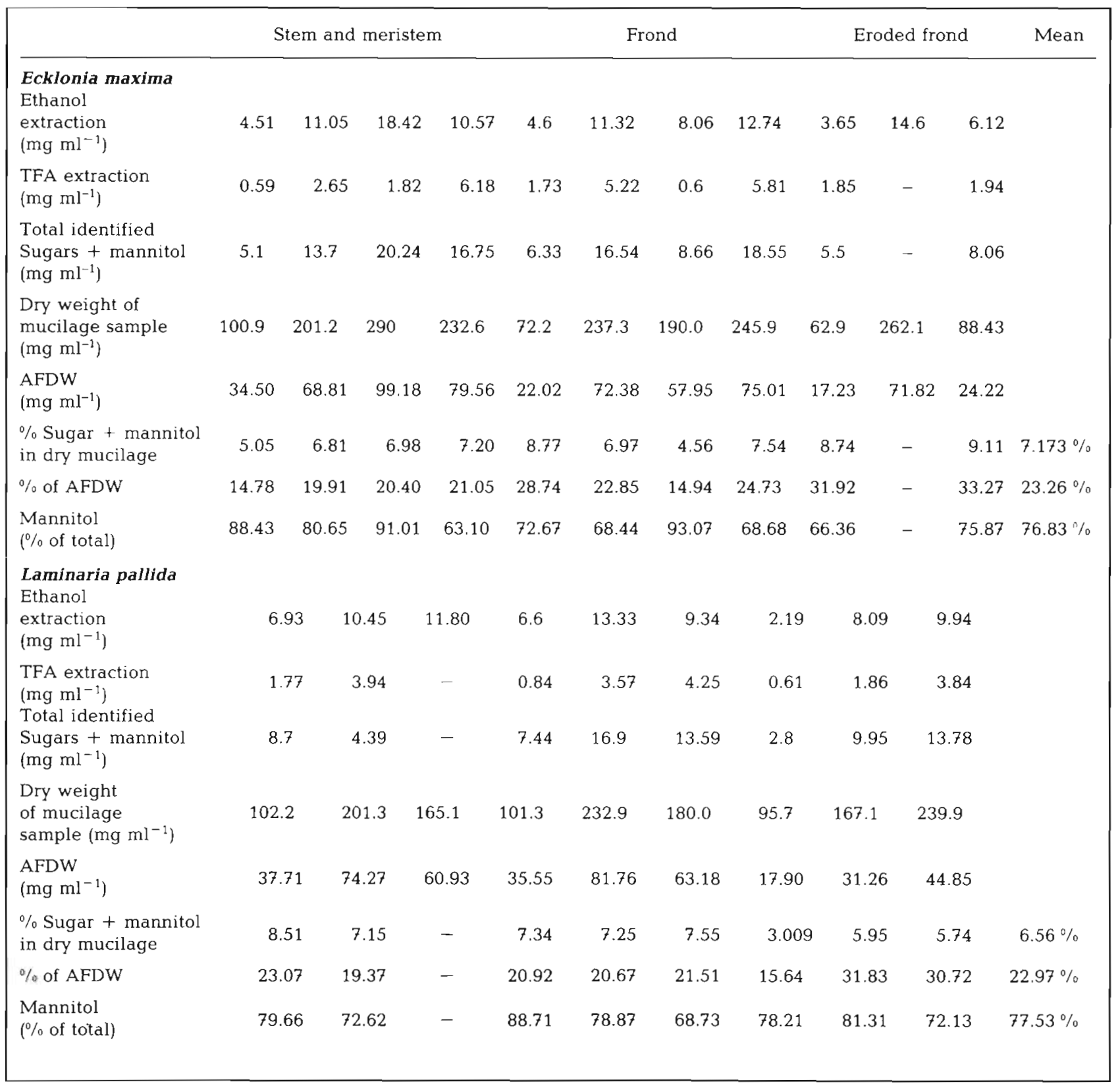


sugars $\alpha$ and $\beta$ galactose, together with trace amounnts of mannose as well as larger quantities of the deoxy sugars $\alpha$ and $\beta$ fucose. Because of the loss of sugars and mannitol from the eroded fronds of Laminaria pallida, a mean value from the stem plus meristem and frond only has been used in a calculation of the energetic contribution of these substances in the exudate whilst a mean of values from all regions has been used to express the percentage sugars and mannitol in mucilage from Ecklonia maxima.

\section{Alginates and Laminarins}

Alginate in mixed samples of dried mucilage from Ecklonia maxima amounted to $4.77 \%$ whilst that in Laminaria pallida was $5.01 \%$. Bomb-calorimetric determination of the energetic content of the crude alginate precipitated with $\mathrm{HCl}$ from calcium alginate extracted from mucilage (p. 48) yielded an energetic contribution of $26.06 \mathrm{kJg}^{-1}$, a value which was then used to calculate the energetic significance of alginates in the mucilage released from kelp during fragmentation.
Laminarins in the dried mucilage were also assayed gravimetrically and anounted to $6.18 \%$ by weight of the dried mucilage in Ecklonia maxima and $3.92 \%$ in Laminaria pallida. These values become $7.23 \%$ in E. maxima and $4.59 \%$ in L. pallida when the $17 \%$ loss in recovery of Iaminarins is taken into account (p. 48). Experimental determination of the energetic content of the precipitated laminarin yielded a value of $14.62 \mathrm{~kJ}$ $\mathrm{g}^{-1} \mathrm{dry}$ weight which, as in alginates, was then used to calculate the energetic contribution of laminarins to mucilage released by the kelps during fragmentation.

\section{Energetic Contribution of Dissolved Organic Compo- nents in Kelp Mucilage}

The quantitative analyses of proteins, lipids, sugars plus mannitol, alginates and laminarins in mucilage from Ecklonia maxima and Laminaria digitata given above allow an assessment of both the gravimetric and energetic contribution of these components to the mucilage released by kelps during the fragmentation process. The results are summarised in Table 9 which

Table 9. Ecklonia maxima and Laminaria pallida. Energy equivalents of major mucilage components expressed as $\mathrm{kJ}^{\left(100 \mathrm{~g}^{-1}\right)}$ dry mucus. Energetic content of dry mucilage is shown as well as the percentage gravimetric and energetic recovery accounted for in the analyses. The mean energy equivalent of the components analysed is $26.57 \mathrm{~kJ} \mathrm{~g}^{-1}$ and can be used to asses the energetic equivalent of gravimetric losses in the analyses

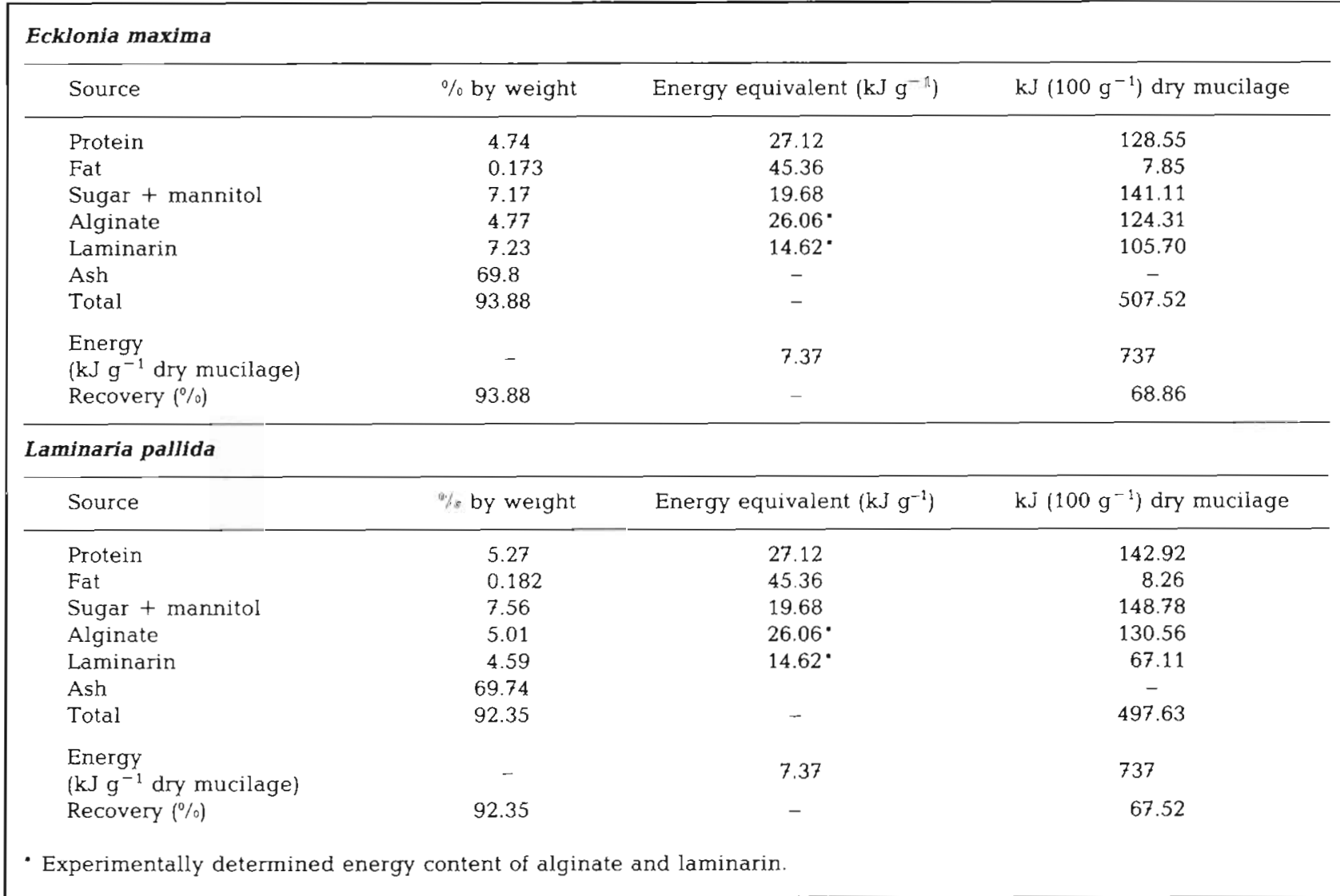


shows the percentage by weight of each component, as well as their energetic yield, the ash content, and the experimentally determined energetic content of the mucilage.

It is apparent that our analyses yielded a gravimetric recovery of as much as $93.88 \%$ in mucilage from Ecklonia maxima and $92.35 \%$ in mucilage from Laminaria pallida. The estimated energetic contribution of each of the components analysed amounts to a total of $507.52 \mathrm{~kJ}(100 \mathrm{~g})^{-1}$ dried mucilage compared with a measured energetic content of $737 \mathrm{~kJ}\left(100 \mathrm{~g}^{-1}\right.$ dried mucilage in E. maxima. The corresponding energetic contribution of the components we analysed in mucilage from L. pallida amounts to $497.63 \mathrm{~kJ}(100 \mathrm{~g})^{-1}$ dried mucilage compared with a measured energetic content of $737 \mathrm{~kJ}(100 \mathrm{~g})^{-1}$ dried mucilage. Our analyses of the principal components thus account for approximately $69 \%$ of the measured energetic content of mucilage from $E$. maxima and $68 \%$ of that from $L$. pallida. In the case of E. maxima the gravimetric recovery reveals a loss of $6.2 \%$ which would yield an additional $164.80 \mathrm{~kJ}$ if the material had an energetic content equivalent to the mean for all organic components of $26.57 \mathrm{~kJ} \mathrm{~g}^{-1}$. The energetic yield for $100 \%$ gravimetric recovery would then become $91.22 \%$ if the gravimetric loss of only $6.2 \%$ were accounted for in terms of organic matter. Equally, in the case of $L$. pallida, the gravimetric loss was $7.65 \%$ which would yield an additional $203.25 \mathrm{~kJ}$ at a mean energetic content of $26.57 \mathrm{~kJ} \mathrm{~g}^{-1}$. The energetic yield for $100 \%$ gravimetric recovery would then become $95.09 \%$ if the loss in gravimetric recovery of only $7.65 \%$ were accounted for in terms of organic components. A 6-7\% loss in gravimetric recovery of organic components is well within the range to be anticipated bearing in mind the limits of experimental accuracy of the techniques used in the assay procedures and the fact that some of the polyol complexes and hexose sugars have not been identified in our chromatographic analyses of carbohydrates.

Comparison of the gravimetric contributions of each component in Table 9 with the independent analysis of major organic components shown in Table 3 also shows a good correspondence. We thus have some confidence in our analyses of the sources of energy in the kelp mucilage and in using the results in a calculation of the quantitative significance of dissolved and particulate organic fractions in the coastal waters in the vicinity of kelp beds.

\section{DISCUSSION: QUANTITATIVE SIGNIFICANCE OF DISSOLVED ORGANIC COMPONENTS IN KELP MUCILAGE}

The quantitative significance of dissolved organic components released during fragmentation of kelp can be calculated from the results of our analyses of dried mucilage, the wet weight: dry weight ratio of the fronds, and from the dry mass of known volumes of mucilage

The mean wet weight: dry weight ratio obtained for fronds of Ecklonia maxima was 1:6.5, a value similar to that of 1:6.675 obtained by N. G. Jarman (personal communication). Thus for $1 \mathrm{~g}$ particulate matter released during fragmentation, there are approximately $5.7 \mathrm{~g}$ mucilage. The mean weight of $10 \mathrm{ml}$ of mucilage was found to be $10.289 \mathrm{~g}$, thus the volume occupied by $5.7 \mathrm{~g}$ mucilage is $5.516 \mathrm{ml}$. The mean dry weight of $10 \mathrm{ml}$ mucilage was found to be $0.662 \mathrm{~g}$, so that $100 \mathrm{mg}$ of the dried mucilage sample analysed (Table 9) represents $1.511 \mathrm{ml}$ of fresh mucilage. Since $1.511 \mathrm{ml}$ fresh mucilage has an energetic content of $0.737 \mathrm{~kJ}$, it follows that the $5.516 \mathrm{ml}$ of mucilage released per dry frond contains $0.737 \times 5.516 /$ $1.511=2.690 \mathrm{~kJ}$. That is, for each $1 \mathrm{~g}$ dry weight of material eroded from the tip of the frond of E. maxima, there are $5.516 \mathrm{ml}$ of mucilage which is equivalent to $2.690 \mathrm{~kJ}$ (or $6.675 \mathrm{~g}$ wet tissue contains $2.69 \mathrm{~kJ}$ of energy in mucilage).

N. G. Jarman (personal communication) has obtained a biomass: production ratio of $1: 4$ for Ecklonia maxima although, as seen from Table 10, this value is subject to variability according to whether the community is a seral or climax one, and probably with depth and other factors. That is, $1 \mathrm{~g}$ wet mass of frond yields $4.0 \mathrm{~g}$ wet tissue year ${ }^{-1}$. From our calculation, $6.675 \mathrm{~g}$ wet frond contains $2.69 \mathrm{~kJ}$ mucilage; therefore $4.0 \mathrm{~g}$ production year ${ }^{-1}$ yields $1.612 \mathrm{~kJ}$ year $^{-1}$ in mucilage. We need only to know the standing crop of the $E$. maxima to arrive at figures for the relative significance of dissolved and particulate losses by the kelp.

In much the same way, we obtained a mean wet weight: dry weight ratio for fronds of Laminaria pallida of $1: 7.928$ which is quite similar to that of $1: 8.008$ reported by Dieckmann (1978) and 1:8.105 by Field et al. (1977). The mean weight of $10 \mathrm{ml}$ of mucilage was found to be $10.27 \mathrm{~g}$, thus the volume occupied by $7 \mathrm{~g}$ of mucilage is $6.816 \mathrm{ml}$. The mean dry weight of $10 \mathrm{ml}$ of mucilage was found to be $0.742 \mathrm{~g}$ so that $100 \mathrm{mg}$ of the dried mucilage sample analysed represents $1.348 \mathrm{ml}$ of fresh mucilage. We obtained an energetic content of $0.737 \mathrm{~kJ}(100 \mathrm{mg})^{-1}$ dried mucilage which is equivalent to $1.348 \mathrm{ml}$ of fresh mucilage. Since $1.348 \mathrm{ml}$ fresh mucilage from L. pallida has an energetic content of $0.737 \mathrm{~kJ}$, it follows that the $6.816 \mathrm{ml}$ mucilage released $\mathrm{g}^{-1}$ of dry frond contains $0.737 \times 6.816 / 1.348=3.727$ $\mathrm{kJ}$. That is, for $1 \mathrm{~g}$ dry weight eroded from the tip of the frond of $L$. pallida, there are $6.816 \mathrm{ml}$ of mucilage which is equivalent to $3.727 \mathrm{~kJ}$ (or $8 \mathrm{~g}$ of wet tissue contain $3.72 \mathrm{~kJ}$ energy in mucilage). 
Table 10. Laminaria pallida and Ecklonia maxima. Standing crop of fronds and annual production in coastal waters off the west coast of Cape Peninsula, South Africa. Data for L. pallida compiled from Dieckmann $(1978)^{+}$and recalculated from Field et al. (1977); that for E. maxima based on recalculations from Mann et al. (1979) assuming a biomass: production of 1:4, and from unpublished data ${ }^{*}$ kindly made available by N. G. Jarman. The calculated energetic contribution of dissolved organic matter released during fragmentation of the kelp is also shown together with its relative significance as a percentage of total energy production as growth. This figure represents the total energy production minus undetermined losses of mucilage from the general surface of the frond

\begin{tabular}{|c|c|c|c|c|c|c|}
\hline & \multicolumn{3}{|c|}{ Laminaria pallida } & \multicolumn{3}{|c|}{ Ecklonia maxima } \\
\hline & $8 \mathrm{~m}^{+}$ & $13 \mathrm{~m}^{+}$ & $\begin{array}{l}\text { Field } \\
\text { et al. }\end{array}$ & Climax* & Seral ${ }^{*}$ & $\begin{array}{l}\text { Marn } \\
\text { et al. }\end{array}$ \\
\hline $\begin{array}{l}\text { Standing crop } \\
\text { Wet mass of frond }\left(\mathrm{kg} \mathrm{m}^{-2}\right)\end{array}$ & 5.870 & 1.770 & 6.712 & 12.75 & 7.18 & 5.5 \\
\hline $\begin{array}{l}\text { Production } \\
\text { Wet mass }\left(\mathrm{kg} \mathrm{m}^{-2} \mathrm{y}^{-1}\right) \\
\text { Dry mass }\left(\mathrm{kg} \mathrm{m}^{-2} \mathrm{y}^{-1}\right) \\
\text { Carbon }\left(\mathrm{g} \mathrm{m}^{-2} \mathrm{y}^{-1}\right) \\
\text { Energy }\left(\mathrm{kJ} \mathrm{m}^{-2} \mathrm{y}^{-1}\right)\end{array}$ & $\begin{aligned} & 27.589 \\
& 3.446 \\
& 869.1 \\
& 37699\end{aligned}$ & $\begin{array}{r}6.177 \\
0.772 \\
194.6 \\
8440\end{array}$ & $\begin{array}{l}41.346 \\
5.164 \\
1302.4 \\
56494\end{array}$ & $\begin{array}{c}51.7 \\
7.755 \\
2387.2 \\
118574\end{array}$ & $\begin{array}{c}27.43 \\
4.109 \\
1265 \\
65333\end{array}$ & $\begin{array}{c}21.92 \\
3.463 \\
1014.6 \\
55063\end{array}$ \\
\hline Biomass: production rafio & $1: 4.7$ & $1: 3.5$ & $1: 6.2$ & $1: 4.1$ & $1: 3.8$ & $1: 4$ \\
\hline $\begin{array}{l}\text { Energy released in } \\
\text { dissolved organic matter } \\
\mathrm{kJ} \mathrm{g}^{-1} \text { wet mass } \mathrm{y}^{-1} \\
\mathrm{~kJ} \mathrm{~m}^{-2} \mathrm{y}^{-1}\end{array}$ & $\begin{aligned} & 2.186 \\
& 12831.8\end{aligned}$ & $\begin{array}{l}1.581 \\
2798.4\end{array}$ & $\begin{aligned} & 2.883 \\
& 19350.7\end{aligned}$ & $\begin{array}{rl} & 1.612 \\
20 & 553.0\end{array}$ & $\begin{array}{rl}1.531 & \\
10 & 995.4\end{array}$ & $\begin{array}{l}1.612 \\
8866\end{array}$ \\
\hline $\begin{array}{l}\% \text { of total energy } \\
\text { production }\end{array}$ & 34.04 & 33.16 & 34.25 & 17.33 & 17.72 & 16.10 \\
\hline
\end{tabular}

Dieckmann (1978) gives a biomass: production ratio of $1: 4.7$ for Laminaria pallida at $8 \mathrm{~m}$ depth although, as seen from Table 10 , this value falls to $1: 3.5$ at $13 \mathrm{~m}$ depth, whilst Field et al. (1977) obtained a production to frond biomass ratio of 1:6.2. From our calculation, $8 \mathrm{~g}$ of wet frond contains $3.72 \mathrm{~kJ}$ mucilage; therefore $4.7 \mathrm{~g}$ of production at $8 \mathrm{~m}$ depth yields $2.816 \mathrm{~kJ} \mathrm{year}^{-1}$ in mucilage. As in the case of Ecklonia maxima, we need to know only the standing crop to arrive at figures for the annual production of energy in particulate and dissolved components during fragmentation of both species of kelp.

Values for standing crop and production of Ecklonia maxima have been assembled in Table 10 from data supplied by N. G. Jarman (personal communication) and recalculated from Mann et al. (1979). In E. maxima, the dry mass of frond is $15 \%$ of the wet mass, whilst the carbon is $29.3 \%$ of the dry mass, and the energetic content in $\mathrm{kJ}$ is $15.9 \mathrm{~g}^{-1}$ dry frond (Mann et al. 1979). Comparable data for Laminaria pallida have been assembled in Table 10 from data of Dieckmann (1978) and Field et al. (1977). In this case Dieckmann (1978) has shown that the dry mass of the frond is $12.5 \%$ of the wet mass whilst carbon is $25.22 \%$ of the dry mass. The energetic content is $10.94 \mathrm{~kJ} \mathrm{~g}^{-1}$ dry frond of $L$. pallida. So the main difference is that $E$. maxima has a greater proportion of dry mass $(15 \%$ of wet weight) and more $\mathrm{kJ} \mathrm{g}^{-1}$ of frond $\left(15.9 \mathrm{~kJ} \mathrm{~g}^{-1}\right)$, whereas L. pallida has a dry mass of only $12.5 \%$ of the wet weight and this has an energetic equivalent of only $10.94 \mathrm{~kJ} \mathrm{~g}^{-1}$.

The energy released as mucilage and its significance relative to total production may be calculated as follows. Dieckmann (1978) has shown, for example, that at $8 \mathrm{~m}$ depth the standing crop of Laminaria pallida is $5.870 \mathrm{~kg}$ wet mass $\mathrm{m}^{-2}$ (Table 10). Since we have shown that $1 \mathrm{~g}$ of wet frond yields $4.7 \mathrm{~g}$ of production which is equivalent to $2.186 \mathrm{~kJ}_{\text {year }}{ }^{-1}$ in mucilage, a standing crop of $5870 \mathrm{~g}$ wet frond yields $2.186 \times 5870=12831.82 \mathrm{~kJ} \mathrm{~m}^{-2} \mathrm{y}^{-1}$ as mucilage. The total energetic content of fresh frond production of $L$. pallida at $8 \mathrm{~m}$ depth is $37699 \mathrm{~kJ} \mathrm{~m}^{-2} \mathrm{y}^{-1}$ (see Table 10 and Dieckmann, 1978). Thus the energy released in mucilage accounts for 12831.82/ $37699 \times 100=34.04 \%$ of the annual energy production of $L$. pallida at $8 \mathrm{~m}$ depth. As might be anticipated, the standing crop and production is lower at a greater depth of $13 \mathrm{~m}$ each $1 \mathrm{~g}$ of wet frond yielding $3.47 \mathrm{~g}$ production year ${ }^{-1}$ or $1.581 \mathrm{~kJ}_{\text {year }}{ }^{-1}$ of mucilage. The mucilage released by the standing crop of $1.770 \mathrm{~kg}$ wet mass $\mathrm{m}^{-2}$ is thus $1770 \times 1.581=2798.37 \mathrm{~kJ} \mathrm{~m}^{-2} \mathrm{y}^{-1}$. The total energetic content of the fresh frond production of $L$. pallida at $13 \mathrm{~m}$ depth is $8440 \mathrm{~kJ} \mathrm{~m}^{-2} \mathrm{y}^{-1}$. Thus the energy released as mucilage accounts for $2798.37 /$ $8440 \times 100=33.16 \%$ of the annual energy production of L. pallida at $13 \mathrm{~m}$ depth.

Similar calculations for Ecklonia maxima are based on the standing crop and energy production of the frond. N. G. Jarman (personal communication), for 
example, has obtained a value of $12.75 \mathrm{~kg} \mathrm{~m}^{-2}$ in a climax community of E. maxima on the west coast of the Cape Peninsula. Since we have shown that $1 \mathrm{~g}$ of wet frond of $E$. pallida yields $4 \mathrm{~g}$ of wet tissue year ${ }^{-1}$ and that this contains $1.612 \mathrm{~kJ}$ year $^{-1}$ in mucilage, a standing crop of $12.75 \mathrm{~kg}$ wet tissue yields $12750 \times 1.612=20553.0 \mathrm{~kJ} \mathrm{~m}^{-2} \mathrm{y}^{-1}$ as mucilage. N. G. Jarman (personal communication; Table 10) gives a total energy production in a climax community of $E$. maxima of $118574 \mathrm{~kJ} \mathrm{~m}^{-2} \mathrm{y}^{-1}$. The relative significance of mucilage production is thus $20553 / 118574 \times 100=$ $17.33 \%$. The equivalent standing crop for a seral community of E. maxima is $7.18 \mathrm{~kg}$ (Table 10) which yields $7180 \times 1.612=11574.16 \mathrm{~kJ} \mathrm{~m}^{-2} \mathrm{y}^{-1}$ as mucilage. The total energy production of a seral community is 65333.4 $\mathrm{kJ} \mathrm{m} \mathrm{m}^{-2} \mathrm{y}^{-1}$ (Table 10) so that the relative significance of energy released as mucilage is $11574.16 /$ $65333.4 \times 100=17.716 \%$ of the total energy production by the seral community.

Calculation of the significance of energy released in mucilage based on data of Mann et al. (1979) recalculated for the frond biomass of Ecklonia maxima and of Field et al. (1977) for that of Laminaria pallida are also included in Table 10 and yield similar values to those cited above. It should be emphasised, however, that both standing crop and biomass to production ratio are subject to considerable variation with both depth and community structure. Any overall estimates of energy production from the coastline as a whole must therefore be treated with a good deal of caution. Nevertheless it is possible to obtain some estimates of the amounts of dissolved and particulate organic matter which are likely to be released from a specific kelp bed of known area. N. G. Jarmann (personal communication) has found, for example, that a kelp bed at Kommetjie on the west coast of the Cape Peninsula, has a shallow water area of 220 ha and a further 480 ha at between $8 \mathrm{~m}$ and $13 \mathrm{~m}$ depth. If we take the average energy production of a climax and seral community of E. maxima, to be $91953 \mathrm{~kJ} \mathrm{~m}^{-2} \mathrm{y}^{-1}$ and that of L. pallida, to be $34211 \mathrm{~kJ} \mathrm{~m}^{-2} \mathrm{Y}^{-1}$ (Table 10), it is possible to calculate the total energy production of the kelp bed, provided the relative standing stocks of E. maxima and L. pallida are known. N. G. Jarman has estimated that the standing stocks for the west coast of the Cape Peninsula south of Cape Columbine are 392160 tons for E. maxima and $117858 \mathrm{t}$ for L. pallida. For a typical kelp bed of $700 \mathrm{ha}$, the standing stocks will be in the proportion of approximately $525 \mathrm{ha}$ (or $525 \times 10^{4} \mathrm{~m}^{2}$ ) of E. maxima and 175 ha (or $175 \times 10^{4} \mathrm{~m}^{2}$ ) of L. pallida. Total energy production for E. maxima from the kelp bed will therefore amount to $48 \times 10^{10} \mathrm{~kJ} \mathrm{y}^{-1}$ of which $18 \%$ or $8.64 \times 10^{10} \mathrm{~kJ} \mathrm{y}^{-1}$ will be in the form of dissolved organic matter. Similarly, total energy production from L. pallida in the kelp bed will amount to
$5.99 \times 10^{10} \mathrm{~kJ} \mathrm{y}^{-1}$ of which $35 \%$ or $2.1 \times 10^{10} \mathrm{~kJ} \mathrm{y}^{-1}$ will be in the form of dissolved organic matter released during fragmentation by eroding kelp.

Total energy released as particulate matter from a kelp bed of 700 ha is thus $39.36 \times 10^{10}$ from Ecklonia maxima plus $3.89 \times 10^{10}$ from Laminaria pallida $=43.25 \times 10^{10} \mathrm{~kJ} \mathrm{y}^{-1}$. Similarly, total energetic release in the form of dissolved organic matter from the kelp bed will be $8.64 \times 10^{10}+2.1 \times 10^{10}=10.74 \times$ $10^{10} \mathrm{~kJ} \mathrm{y}^{-1}$. This value represents a very large annual volume of dissolved organic matter. In E. maxima, for example, for each $1 \mathrm{~g}$ dry tissue eroded from the tip there are $5.516 \mathrm{ml}$ which contain $2.69 \mathrm{~kJ}$ (p. 55) whereas in L. pallida each $1 \mathrm{~g}$ dry tissue eroded represents $6.816 \mathrm{ml}$ which contains $3.72 \mathrm{~kJ}$. (p. 55). A mean value for both species is thus $3.21 \mathrm{~kJ}=6.05 \mathrm{ml}$ mucilage released during fragmentation. An annual dissolved energy production during fragmentation from the tips of the kelp of $10.74 \times 10^{10} \mathrm{~kJ}$ would thus be equivalent to the release of $6.05 / 3.21 \times 10.74 \times 10^{10}$ $\mathrm{ml}=20.24 \times 10^{7} \mathrm{l}$ into shallow water, to which should be added undetermined losses of mucilage from the surface of the fronds (p. 46).

Field et al. (1977) have recently reviewed the quantitative significance of primary production of kelp in the maintenance of secondary production in the coastal waters off the Cape Peninsula. They showed that primary production and annual energetic release by kelp beds into the nearshore waters is high compared with the contribution of phytoplankton and in this respect their results resemble those on the energetic contribution of mixed communities of algae (Mann, 1973) and saltmarsh plants (Penhale and Smith, 1977) to coastal waters. The results presented above show in addition that as much as $18 \%$ of the energetic contribution of Ecklonia maxima and $35 \%$ of that of Laminaria pallida is released during fragmentation as dissolved organic matter which is probably more immediately utilisable by heterotrophic organisms than the particulate component.

The fate of such dissolved organic components of the mucilage following release during fragmentation of the kelp is not yet known, although some of the essential fatty acids of the linoleic (18:2) and linolenic (18:3) series may be of considerable significance as dietary components for consumer organisms, particularly when the large annual volumes of mucilage are taken into account (Holland, 1978; see also p. 51). R. A. Carter has, however, recently found that dissolved organic carbon levels in the water column near to the kelp beds at our study site at Oudekraal, Cape Peninsula, rise to as much as $20 \mathrm{mgl}^{-1}$ during periods of strong south-east winds when upwelling of the water occurs, and subsequently fall in calm weather to less than $5 \mathrm{mg} \mathrm{l}^{-1}$ within $24 \mathrm{~h}$ without an accompanying 
phytoplankton bloom. Our data shows that there are approximately $74200 \mathrm{mg}$ dry matter $\mathrm{l}^{-1}$ of mucilage extracted from Laminaria pallida (p. 55). If the dissolved organic matter recorded in the water column solely represents that released by the kelp during fragmentation, the dilution is thus of the order of $1: 3700$, and this material is evidently utilised within $24 \mathrm{~h}$ principally by micro-heterotrophic organisms rather than by phytoplankton.

These results suggest that the dominant carbohy. drates such as the polyol mannitol may represent a primary energy resource for rapid heterotrophic utilisation by the micro-organisms inhabiting the water column in the vicinity of kelp beds. Wheeler (1976) has shown that dissolved carbohydrates and subparticulate organic material exported from saltmarshes may also be of major significance for heterotrophic organisms in the coastal waters off Georgia, USA. It seems likely, however, that more complex molecules such as alginates and laminarins, as well as the structural components comprising the particulate and subparticulate fractions, may be utilised over a longer period of time and thus contribute to the stability of the energy resources available for utilisation by the microheterotrophic community.

Acknowledgements This work could not have been carried out without extensive advice and technical assistance given to us by colleagues in the University of Cape Town. We wish to acknowledge in particular the technical advice given to us by Professor A. M. Stephen and Dr. E. H. Merrifield of the CSIR Carbohydrate Research Unit, Dr. D. W. Brandt of the Biochemistry Department as well as Dr. A. A. Spark and Miss C. M. Henderson of the Fishing Industry Research Institute. We are also grateful for the use of technical facilities in the Botany Department. We wish to thank Messrs N. G. Jarman of the Sea Fisheries Branch and R. A. Carter (NRIO) for permission to cite their unpublished data as well as for their comments on a draft of this paper. This work was funded principally from SANCOR through the kelp bed project of the University of Cape Town.

\section{LITERATURE CITED}

Ackman, R. G., Tocher, C. S., McLachlan, J. (1968). Marine phytoplankter fatty acids. J. Fish. Res. Bd Can. 25: $1603-1620$

Adams, G. A. (1965). Complete acid hydrolysis. In: Whistler, R. C. (ed.) Methods in carbohydrate chemistry, V, General polysaccharides. Academic Press, New York, London, pp. 260-276

Anderson, G. C., Zeutschel, R. P. (1970). Release of dissolved organic matter by marine phytoplankton in coastal and offshore areas of the north-east Pacific Ocean. Limnol. Oceanogr. 15: 402-407

Berman, T., Holm-Hansen, O. (1974). Release of photoassimilated carbon as dissolved organic matter by marine phytoplankton. Mar. Biol. 38: 305-310

Björndal, H., Hellerqvist, C. G., Lindberg, B., Svensson, S. (1970). Gas-liquid chromatography and mass spec- trometry in methylation analyses of polysaccharides. Angew. Chem. Internat. Edit. 9: 643-653

Bligh, E. C., Dyer, W. J. (1959). A rapid method of total lipid extraction and purification. Can. J. Biochem. Physiol. 37 : 911-912

Brylinsky, M. (1977). Release of dissolved organic matter by some marine macrophytes. Mar. Biol. 39: 213-220

Chapman, V J. (1950). Seaweeds and their uses, Methuen, London

Choi, C. I. (1972). Primary production and release of dissolved organic carbon from phytoplankton in the western North Atlantic Ocean. Deep Sea Res. 19: 731-735

Conover, R. J. (1978). Transformation of organic matter. In: Kinne, O. (ed.) Marine ecology, Vol. IV, Dynamics. Wiley, Chichester, pp. 221-449

Craigie, J. S. (1974). Storage products. In: Stewart, W.D.P.(ed.) Algal physiology and biochemistry. Bot. Monogr. 10, Blackwell, Oxford, pp. 206-235

Dieckmann, G. S. (1978). Aspects of growth and production of Laminaria pallida (Grev.) J. Ag. off the Cape Peninsula. M. Sc. thesis, University of Cape Town

Elyakova, L. A., Zvyagintseva, T. N. (1974). A study of the laminarins of some far-eastern brown seaweeds. Carbohydrate Research 34: 241-248

Field, J. G., Griffiths, C. L., Griffiths, R. J., Jarman, N. G., Zoutendyk, P., Velimirov, B., Bowes, A. (1980). Variation in the structure and biomass of kelp communities along the west coast of South Africa. Trans. R. Soc. S. Afr. 43 (in press)

Field, J. G., Jarman, N. G., Dieckmann, G. S., Griffiths, C. L., Velimirov, B., Zoutendyk, P. (1977). Sun, waves, seaweed and lobsters: The dynamics of a west-coast kelp bed. $S$. Afr. J. Sci. 73: 7-10

Folin, O., Malmros, H. (1929). An improved from of Folin's micro method for blood sugar determinations. J. biol Chem. 83: 115-120

Fong, W., ODor, R. K. (1979). D-mannitol interferes with amino acid analysis of marine organisms. J. Fish. Res. Bd Can. 36: 1134-1137

Guarnieri, M., Johnson, R. M. (1970). Essential fatty acids. Adv. Lipid Res. 8: 115-174

Harlin, M. M. Craigie, J. S. (1975). The distribution of photosynthate in Ascophyllum nodosum and its relation to epiphytic Polysiphonia lanosa. J. Physiol. 11: 109-113

Hatcher, B. G., Chapman, A. R. O., Mann, K. H. (1977). An annual carbon budget for the kelp Laminaria longicruris. Mar. Biol. 44: 85-96

Haug, A. (1965). Alginic Acid: Isolation and fractionation with potassium chloride and manganous ions. In: Whistler, R. L. (ed.) Methods in carbohydrate chemistry V, General polysaccharides. Academic Press, New York, London. pp. 69-73

Hellebust, J. A. (1965). Excretion of some organic compounds by marine phytoplankton. Limnol. Oceanogr. 10; 192-206

Holland, D. L. (1978). Lipid reserves and energy metabolism in the larvae of benthic marine invertebrates. In: Mullins, D. C., Sargent, J. R. (eds) Biochemical and biophysical perspectives in marine biology, Vol. 4. Academic Press, London, New York, pp. 85-123

Holland, D. L., Gabbott, P. A. (1971). A micro-analytical scheme for the determination of protein, carbohydrate, lipid and RNA levels in marine invertebrate larvae. J. mar. biol. Ass. U. K. 51: 659-668

Holland, D. L., Hannant, P. J. (1973). Addendum to a microanalytical scheme for the biochemical analysis of marine invertebrate larvae. J. mar. biol. Ass. U. K. 53: 833-838

Holligan, P. M. (1971). Routine analysis by gas liquid 
chromatography of soluble carbohydrates in extracts of plant tissues. I. A review of techniques used for the separation, identification and estimation of carbohydrates by gas-liquid chromatography. New Phytol. 70: 239-269

Holligan, P. M., Drew, E. A. (1971). Routine analysis by gasliquid chromatography of soluble carbohydrates in extracts of plant tissues. II. Quantitative analysis of standard carbohydrates and the separation and estimation of soluble sugars and polyols from a variety of plant tissues. New Phytol. 70: 271-297

Ignatiades, L. (1973). Studies on the factors affecting the release of organic matter by Skeletonema costatum (Greville) Cleve in field conditions. J. mar, biol. Ass. U. K. 53: 923-935

Jensen, A., Stein, J. R. (eds) (1978). Proceedings of the international seaweed symposium 9 . Science Press, Princeton, USA

Johnston, C. S., Jones, R. G., Hunt, R. D. (1977). A seasonal carbon budget for a laminarian population in a Scottish sea loch. Helgoländer wiss. Meeresunters. 30: 527-545

Khailov, K. M., Burlakova, Z. P. (1969). Release of dissolved organic matter by marine seaweeds and distribution of their total organic production to inshore communities. Linmol, Oceanogr. 14: 521-527

Lee, R. F., Barnes, A. T. (1975). Lipids in the mesopelagic copepod, Gaussia princeps. Wax ester utilisation during starvation. Comp. Biochem. Physiol. 52B: 265-268

Levin, R. A. (1974). Biochemical Taxonomy. In; Stewart, W. D. P. (ed.) Algal physiology and biochemistry. Bot. Monogr. 10, Blackwell Oxford, pp. 1-39

Lewis, D. H., Smith, D. C. (1967a). Sugar alcohols (Polyols) in fungi and green plants I. Distribution, physiology and metabolism. New Phytol. 66: 143-184

Lewis, D. H., Smith, D. C. (1967b). Sugar alcohols (Polyols) in fungi and green plants II. Methods of detection and quantitative estimation in plant extracts. New Phytol. 66: 185-204

Lowry, O. M., Rosebrough, N. J., Farr, A. L., Randall, R. J. (1951). Protein measurement with the folin phenol rea gent. J. Biol. Chem. 193: 265-275

Mann, J. H. (1973). Seaweeds: their productivity and strategy for growth. Science, N. Y. 182: 975-981

Mann, K. H., Jarman, N. G., Dieckmann, G. S. (1979). Development of a method for measuring the productivity of Ecklonia maxima (Osbeck) Papenf. Trans. R. Soc. S. Afr. 44: $27-42$

Mackie, W., Preston, R. D. (1974). Cell wall and intercellular region polysaccharides. In: Stewart, W. D. P. (ed.) Algal physiology and biochemistry. Bot. Monogr. 10, Blackwell, Oxford, pp. 40-85

Marsh, J. B., Weinstein, D. B. (1966). Simple charring method for determination of lipids. J. Lipid Res. 7, 574-576

McDowell, R. H. (1973). Properties of Alginates. 3rd (revised) ed. Alginate Industries Ltd., London

Metcalfe, L. D., Schmitz, A. A., Pelka, J. R. (1966). Rapid preparation of fatty acid esters from lipids for gas liquid chromatography. Anal. Chem. 38: 514

Moebus, K., Johnson, K. M. (1974). Exudation of dissolved organic carbon by brown algae. Mar. Biol. 26: 117-125

Moebus, K., Johnson, K. M., Sieburth, J. McN. (1974). Rehydration of desiccated intertidal brown algae: release of dissolved organic carbon and water uptake. Mar. Biol. 26: $127-134$
Newell, R. C. (1979). Biology of Intertidal Animals. 3rd ed Marine Ecological Surveys, Faversham, Kent, U. K

Penhale, P. A., Smith, W. O. (1977). Extraction of dissolved organic carbon by eelgrass (Zostera marina) and its epiphytes. Limnol. Oceanogr. 22: 400-407

Percival. E. (1968). Marine algal carbohydrates. Oceanogr Mar. Biol. Ann. Rev. 6: 137-161

Rogers, H. J., Perk, H. R. (1968). Cell walls and membranes E \& F. N. Spon Ltd., London

Ryther, J. H., Menzel, D. W., Hulbert, E. M., Lorenzen, C. J., Corwin, N. (1971). The production and utilisation of organic matter in the Peru coastal current. Investigación pesq. $35: 43-59$

Sieburth, J. MCN. (1969). Studies on the algal substances in the sea. 3. The production of extracellular organic matter by littoral marine algae. J. exp. mar. Biol. Ecol. 3: 290-309

Sieburth, J. McN. (1976). Bacterial substrates and productivity in marine ecosystems. Ann. Rev. Ecol. Syst. 7: 259-285

Sinnhuber, R. D., Castell, J. D., Lee, D. J. (1972). Essential fatty acid requirements of the rainbow trout, Salmo gaireseri. Fedn Proc. Fedn Am. Socs exp. Biol. 31: 1436-1441

Sorokin, Yu. I (1978). Decomposition of organic matter and nutrient regeneration. In: Kinne, $O$. (ed.) Marine ecology, Vol. IV, Dynamics. Wiley, Chichester, pp. 501-616

Spackman, D. H., Stein, W H., Moore, S. (1958). Automatic recording apparatus for use in the chromatography of amino acids. Anal. Chem. 30: 1190-1206

Spark, A. A., Louw, P. (1973). Long chain mono-unsaturated fatty acids in South African fish oils and other products Ann. Rep. Fish, Ind. Res. Inst. 27, 49-51

Stephen, A. M. (1979). Plant Carbohydrates. In: Pirson, A., Zimmermann, M. H. (eds) Encyclopedia of plant physiology 8, Springer-Verlag, Heidelberg, pp. 555-584

Sweeley, C. C., Bentley, R., Makita, M., Wells, W. W. (1963). Gas liquid chromatography of trimethylsilyl derivatives of sugars and related substances. J. Am. chem. Soc, 85 $2497-2507$

Thomas, J. P. (1971). Release of dissolved organic matter from natural populations of marine phytoplankton. Mar. Biol. 11: $311-323$

Velimirov, B. (1979). Fatty acid composition of kelp on the west coast of South Africa and some ecological implications. Botanica Mar. 22: 237-240

Velimirov, B., Field, J., Griffiths, C. L., Zoutendyk, P. (1977). The ecology of kelp bed communities in the Benguela upwelling system. Analysis of biomass and spatial distribution. Helgoländer wiss. Meeresunters. 30: 495-518

Von Holdt, M. M., Ligthelm, S. P., Nunn, J. R. (1955). South African seaweeds: seasonal variations in the chemical composition of some Phaeophycaea. J. Sci. Food Agric. 6: 193-197

Wangersky, P. J. (1978). Production of dissolved organic matter. In: Kinne, O. (ed.) Marine ecology, Vol. IV, Dynamics. Wiley, Chichester, pp. 115-220

Watanabe, T., Ackman, R. G. (1972). Effect of unicellular algal lipids on oyster lipids and their fatty acid composition. J. Fish. Res. Bd Can. (Tech. Rept. No. 334): 1-41

Wheeler, J. R. (1976). Fractionation by molecular weight of organic substances in Georgia coastal water. Limnol. Oceanogr. 21:847-852

Wood, B. J. B. (1974). Fatty acids and saponifiable lipids. In: Stewart, W. D. P. (ed.) Algal physiology and biochemistry. Bot. Monogr. 10, Blackwell, Oxford, pp. 236-265 